\title{
CATIVIDADE MARCÁRIA COMO FUNDAMENTO DA \\ RESPONSABILIDADE CIVIL POR RISCO EM PROL DOS CONSUMIDORES
}

Fernando Antônio de Vasconcelos

Mestre e doutor em Direito Civil pela UFPE e professor da UFPB e do Unipê. E-mail: fer.mengo@uol.com.br

André Luiz Cavalcanti Cabral

Mestre em Ciências Jurídicas com linha de pesquisa em Direito Econômico; doutorando em Direitos Humanos e Desenvolvimento pela UFPB. E-mail: cabral@ crc.adv.br

\section{Resumo}

A sociedade pós-moderna pode ser tida como sociedade de risco. A partir da ideia de Ulrich Beck de que o conhecimento adquirido que permite o atual modelo de desenvolvimento gera riscos incontroláveis, tenta-se nesse estudo fazer uma validaçấo da catividade marcária como fundamento de responsabilidade civil por riscos. A força das marcas como balizas fundamentais no processo econômico da atualidade é vista como vetor de responsabilidade em prol dos consumidores como classe de vulneráveis. A dificuldade dos consumidores, no processo de responsabilização pelos danos sofridos nas relaçôes consumeristas, continua presente. A cadeia de fornecimento é complexa e se forma por meio de uma rede contratos que acentua a vulnerabilidade do consumidor. Acatividade marcária permite a identificação dos partícipes da cadeia de fornecimento pelo compartilhamento da marca. A proposta neste artigo, é o fortalecimento da idéia da catividade marcária como paradigma de responsabilização a partir da marca, com a teoria do risco, examinando-se sua viabilidade de enquadramento no parágrafo único do artigo 927 do Código Civil Brasileiro.A metodologia se baseará numa vertente jurídico-econômica e partirá de uma análise indutiva e levantamento de bibliografias, com o marco teórico de Ulrich Beck, Antonny Giddens e Cláudia Lima Marques.

\section{Palavras-chave}

Sociedade de Risco; Catividade marcária; Responsabilidade. 


\section{Abstract}

The postmodern society can be seen as risk society. From the Ulrich Beck's idea that the acquired knowledge allows the current development model, but its generates uncontrollable risks, this study attempts to make a validation of trademark captivity theory as the basis for civil liability for risk. The strength of the brands as fundamental goals in today's economic process is seen as a vector of liability for consumers as a vulnerable class. The difficulty of consumers in the process of accountability for damages suffered in their relations is still present. The supply process is complex and is formed by a network arrangements which stresses the consumer's vulnerability. The trademark captivity allows the identification of an economic group participants by sharing the brand. The proposal in this article, is to strengthen the idea of captivity mark as accountability paradigm from the brand with the theory of risk, examining its feasibility framing the sole paragraph of Article 927 of the Brazilian Civil Code. The methodology will be based on a legal-economic aspect and depart from an inductive analysis and bibliographic surveys, with the theoretical framework of Ulrich Beck, Antonny Giddens and Claudia Lima Marques.

\section{Key words}

Risk Society; Trademark Captivity; Liability.

\section{Introdução}

A sociedade atual tem características tão plurais que é de difícil definição ou mesmo categorização. Entre as diversas tentativas de definição dessa sociedade, a ideia do risco se apresenta como uma hipótese interessante de consolidação de um novo momento civilizatório. Momento esse ainda mais atraente, pós o esfacelamento de algumas dicotomias fundamentais na geopolítica global, como o velho conflito capitalismo versus socialismo e o fim da chamada guerra fria.

Esse admirável mundo novo global clama por solidariedade, entre ondas de nacionalismo e preconceitos enraizados. A humanização do direito ainda não conquistou sua efetividade e tudo, por não raras vezes, parece um grande palco de atores utilitaristas que, ao fim, desempenham seus papéis apenas com o intuito dos benefícios econômicos que podem ser colhidos. O quadro é mais grave ainda quando se trata do direito dito privado. Porém, a ânsia de produção da necessária riqueza para sustentação de modelos sociais consumistas torna o risco incontrolável e elemento inerente da sociedade. Viver em sociedade passar a ser arriscar-se, muito além de uma força imponderável, mas como conseqüência de opção por um modelo de ilimitadas necessidades satisfeitas por múltiplas hipóteses. Assim, os riscos não são imprevisíveis, mas ao contrário, previstos e assimilados como naturais, num sistema onde a engrenagem não pode parar, e eventuais reparos devem ser feito em movimento, mesmo que os danos sejam severos. 
Nesse contexto, alguns grupos sociais, por mais que se possa identificar alguma organização ou mobilização, seja política, social ou mesmo econômica, em seu benefício, continuam em acentuada posição de vulnerabilidade. Uma vulnerabilidade tão plural, cujo reflexo jurídico é, apenas, mais uma face desse prisma de hipossuficiências. Uma potencialidade jurídica mitigada por arcaicos modelos e instrumentos que não resolvem seus anseios jurídicos, nem sequer, efetivam os direitos basilares já conquistados. Nesse vasto rol de vulneráveis estão os consumidores, ao lado de outros grupos, como por exemplo, os menores, os idosos, os deficientes, os indígenas, as pequenas empresas. Para fins dessa abordagem, será os consumidores o grupo de vulneráveis objeto do interesse investigativo.

A responsabilidade civil é assim desafiada pelo risco. Afinal, notadamente o desenvolvimento econômico capitalista pautado na livre iniciativa e na proteção da propriedade privada, não pode renegar o risco de danos. Por isso, os riscos inerentes a uma atividade econômica é fator de análise, desde seu planejamento prévio até a sua dissolução. O mercado global é um mercado alicerçado na oferta e contratação em massa de consumidores, onde as necessidades são criadas por um discurso publicitário que se notabiliza pela visibilidade das marcas.

As marcas como grandes faróis do mercado atraem os consumidores navegantes para o seu porto nem sempre seguro. A proposta, no presente artigo, é uma análise de responsabilização a partir da marca empresarial registrada, na sociedade de risco, fundamentada no fenômeno de sua catividade. Há a tentativa de demonstrar e reforçar a utilização da marca como vetor da responsabilidade civil por meio da catividade marcária. Adiante, tratar-se-á da sociedade de risco, para contextualizar o modelo de nossa sociedade atual. Em seguida, aborda-se a catividade marcária com a explicitação de suas bases teóricas para sua definição. Finalmente, aborda-se a catividade marcária como fundamento da responsabilidade por risco.

\section{Da Sociedade de Risco}

A sociedade de risco é uma idéia que foi consagrada a partir da obra de Ulrich Beck $^{1}$. Na sociedade moderna atual, para alguns pós-moderna ${ }^{2}$, alta modernidade ${ }^{3}$ ou modernidade tardia, o conhecimento adquirido que permite o atual modelo de desenvolvimento gera riscos incontroláveis. Principalmente, a produção de bens para a satisfação das necessidades da humanidade, provoca inexoravelmente riscos. A sociedade industrial

1 Cf. BECK, Ulrich. Sociedade de Risco. 2 ed. São Paulo: Editora 34, 2013.

2 Cf. MARQUES, Cláudia Lima. O novo direito Privado e a proteção dos vulneráveis / Claudia Lima Marques, Bruno Miragem. São Paulo: Editora Revista dos Tribunais, 2012.

3 CF. GIDDENS, Anthony. Modernidade e identidade / Anthony Giddens; tradução, Plínio Dentzien. Rio de Janeiro: Jorge Zahar Ed., 2002. 
é vista pelos partícipes da teoria da sociedade de risco em um contexto de êxito duvidoso, pois estaria o modelo atual denunciando que os altos perigos criados são incontroláveis e potencialmente destrutivos de nossa civilização. Na síntese de Alexandre (2000, p. 154):

Ainda em Giddens, um entendimento do que vem a ser risco na alta modernidade, significa urna consciência de existência de um lado sombrio da modernidade, coisa que os fundadores da sociologia, Marx, Durkheim e Weber deixaram de certa forma de considerar. Nestes três autores, para Giddens, as conseqüências da modernidade em termos de uma preocupaçáo com os limites do uso da racionalidade cientifica e dos danos ambientais resultados das praticas industriais não foram considerados. Marx aduzia claramente a uma superação das necessidades impostas pela natureza tomada a partir do aperfeiçoamento do uso da técnica, de maneira tal que o incremento da industrialização somente deveria libertar mais o trabalhador e que nesse rumo a luta de classes estaria com seus dias contados. Durkheim precisava que a felicidade da sociedade moderna era alcançável exatamente através do industrialismo, se aperfeiçoada a solidariedade orgânica com cooperativas e associativismos. Weber desprezava a modernidade pela sua crueza racionalizante e burocratizante, porém ele nunca imaginou que essas duas características da modernidade se somariam a uma perda de controle com riscos sociais e ambientais."

O Mesmo que se possa entender que alguns riscos seriam inevitáveis, na verdade, a ampla maioria deles, são aceitáveis, no sentido em que, simplesmente, são assumidos como necessários na busca do bem maior.

"Na modernidade tardia, a produção social de riqueza é acompanhada sistematicamente pela produção social de riscos. Conseqüentemente, aos problemas e conflitos distributivos da sociedade da escassez sobrepóemse os problemas e conflitos surgidos a partir da produção, definição e distribuição de riscos científico-tecnologicamente produzidos." (BECK, 2013, p. 23)

A forma de produção do mundo contemporâneo impóe níveis nunca imaginados de utilização de recursos naturais ou não. A idéia de risco não é simplesmente a noção de perigo. A humanidade sempre conviveu com o perigo, seja ele provindo da natureza, ou do próprio homem, o "outro". Contudo, no processo de evolução da organização civilizatória, o homem foi transformando seu meio ambiente, na tentativa de reduzir seus riscos. Obviamente, ponto importantíssimo é a evolução dos meios econômicos, com sua propulsão fincada no acúmulo de conhecimento que gerou, a cada dia, novas tecnologias. Ao final, a natureza parecia estar sendo controlado, o outro, também, poderia ser domado.

No contexto de tantos riscos, cabe a reflexão do papel do conhecimento. Embora, nessa oportunidade de estudo, o espaço não seja adequado, é importante fincar a idéia de 
que a sociedade pós-moderna admite que seu conhecimento é, simplesmente e naturalmente, arriscado. $\mathrm{O}$ conhecimento científico, apesar de aniquilador dos mitos e superstiçôes, está longe de ser seguro. É um conhecimento também transitório, até ansioso, ávido a lucrar, e, por isso, nem sempre cauteloso.

"No turbilhão de mudanças, é muito mais atraente o conhecimento criado para usar e jogar fora, o conhecimento pronto para utilização e eliminação instantâneas, o tipo de conhecimento prometido pelos programas de computador que entram e saem das prateleiras das lojas num ritmo cada vez mais acelerado." (BAUMAN, 2010, p. 42)

Ou seja, o mesmo conhecimento que liberta do misticismo e ilumina as trevas, acabou por gerar novos riscos que não existiam, e que passam a representar, quiçá, perigos mais destrutivos. $\mathrm{O}$ que dizer de um ataque bélico nuclear, por exemplo?Nesses cenários, os riscos foram potencializados a um patamar nunca visto. Assim, "[...] no processo de modernização, são desencadeado riscos e potenciais de autoameaça numa medida até então desconhecida." (BECK, 2013, p. 23).

"A modernidade reduz o risco geral de certas áreas e modos de vida, mas ao mesmo tempo introduz novos parâmetros de risco, pouco conhecidos ou inteiramente desconhecidos em épocas anteriores. Esses parâmetros incluem riscos de alta conseqüência, derivados do caráter globalizado dos sistemas sociais da modernidade. O mundo moderno tardio - o mundo do que 12 Modernidade e identidade chamo de alta modernidade - é apocalíptico não porque se dirija inevitavelmente à calamidade, mas porque introduz riscos que gerações anteriores não tiveram que enfrentar. Por mais que tenha havido progresso na negociação internacional e no controle das armas, uma vez que continuarem a existir armas nucleares, ou mesmo o conhecimento necessário para construí-las, e uma vez que a ciência e a tecnologia continuarem a se envolver com a criação de novos armamentos, o risco da guerra maciçamente destrutiva permanecerá." (GIDDENS, 2002, pp.11-12).

A própria questão energética é outro bom exemplo. Os países consomem seus recursos naturais em busca de energia, em fontes não renováveis, que colocam em risco até mesmo as fontes renováveis. $\mathrm{O}$ tema da energia nuclear náo pode deixar de ser polêmico, as pequenas amostras de seus acidentes, como os caso de Chernobyl (1986) ${ }^{4}$ e Fukushima (2011), são suficientes para justificar uma reflexão profunda sobre as escolhas feitas, bem como, para evidenciar que os riscos são colossais. Na temática nuclear, todos são vulneráveis, pois a radioatividade não escolhe gênero, raça, nacionalidade, ou posiçáo econômica.

4 O caso de Chernobyl é um dos fatores que inspira a teoria de Ulrich Beck como o próprio autor confessa na suas palavras acerca de sua própria obra (BECK, 2013, pp. 07-10). 
Numa sociedade onde os riscos são tantos e tão severos, algo necessita ser feito para se possível eliminá-los, quando impossível a eliminação, mitigá-los e, quando materializado o risco em danos, a socialização destes últimos é preciso. O problema proposto seria como melhor equalizar os riscos no meio da sociedade. Se é verdade que muito se tem feito, no que tange a reflexóes dos grandes riscos, como os ambientais, por exemplo, com uma ampla divulgação da mídia de seus problemas, pressóes políticas por leis mais severas, tratados internacionais como o de Kioto, o mesmo já não se pode referenciar quanto aos danos menores.

A sociedade de risco consiste numa realidade formada por fluxos de riscos, em diversos níveis e escalas interligadas em dimensóes difusas, não sempre muito claras ou perceptíveis, onde ninguém está inatingível. Como afirma Beck (2013, p. 36), "Atingese, por assim dizer, uma superprodução de riscos, que em parte se relativizam, em parte se complementam, em parte invadem o terreno uns dos outros." Contudo, no mercado acirrado por uma concorrência feroz, cada agente competidor, a sua maneira, luta com afinco para conquistar espaços e se esquivar dos riscos que permeiam seu espaço, seja ele o produtor ou não dos perigos que marcam sua trajetória. É o que Beck (2013, p. 36) explicita afirmando que "Cada ponto de vista interessado procura armar-se com definiçóes de risco, para poder dessa maneira rechaçar os riscos que ameaçam seu bolso.”

Obviamente, os meios de defesa anti-risco perpassam por armas também plurais. Há aqueles instrumentos econômicos (seguros, provisóes de recursos para atender as demandas geradas pelos riscos, etc.), jurídicas (tentativa de exclusão de responsabilidades contratualmente, cláusulas penais, etc.) e, obviamente políticas (pressão nos legisladores por normas que isentem responsabilidade ou imponha limites, propagaçáo de valores que interessem na administração dos riscos, etc.), todos em alguma medida são sociais. MARQUES e MIRAGEM afirmam que existem "duas tendências mundiais: a criação de leis e fontes específicas para a proteçáo dos vulneráveis e o uso necessário da teoria do diálogo das fontes, sejam de direito público ou de direito privado, para a efetiva e completa defesa dos mais fracos na sociedade.” (MARQUES; MIRAGEM, 2012, p. 210).

Apesar do que possamos chamar de resistência aos riscos ser uma prática geral, as estratégias adotadas oscilam muito entre cada grupo, principalmente, quando se trata dos vulneráveis. No caso da vulnerabilidade do consumidor, há hoje diversos estudos que fortalecem o seu reconhecimento e que afastam a idéia da autonomia da vontade ou liberdade de escolha como traço marcante deste grupo. $\mathrm{O}$ combate à idéia da autonomia do consumidor gerou o reconhecimento de que:

[...] o mito da soberania do consumidor é um reflexo do mito liberal do contratualismo, que reduz toda a vida em sociedade - nomeadamente a vida econômica - a relaçóes contratuais livremente assumidas por indivíduos livres, independentes e iguais em direitos, cada um dos quais 
dispõe de informação completa sobre todas as alternativas possíveis e sabe perfeitamente o que quer. (NUNES, 2003, p. 57).

Ademais, sendo os consumidores um grupo de vulneráveis amplo, a sua homogeneidade econômica, também, é um mito. Existem os hipervulneráveis ${ }^{5}$, os pobres consumidores possuem ainda menos condições de resistências aos riscos que os mais abastados. Eis a desigual distribuição dos riscos, seja entre grupos ou, internamente, no seio de um grupo. Nas palavras de Beck (2013, p.41) "A história da distribuição de riscos mostra que estes se atêm, assim como as riquezas, ao esquema de classe - mas de modo inverso: as riquezas se acumulam em cima, os riscos em baixo.” Embora, o próprio Beck em outros momentos defenda que a sociedade de riscos da modernidade tardia se afasta da modernidade industrial pela superação da idéia de classes, pois os grandes riscos "civilizacionais" colocariam todos em xeque. Inclusive os que se aproveitaram economicamente e produziram os riscos, são também atingidos. A esse processo ele denomina de efeito bumerangue. (BECK, 2013, pp. 23-28; 41-47).

O acúmulo de riqueza é sinônimo de maior proteção contra os riscos, por isso a fundamentalidade da propriedade privada. O liberalismo econômico enaltece a propriedade privada, tanto que, constitucionalmente ${ }^{6}$, está consagrada como direito fundamental, além de ser exaustivamente disciplinada no âmbito infraconstitucional. ${ }^{7} \mathrm{~A}$ função social é exigida também constitucionalmente como sombra de legitimação de sua titularidade, o que faz aparentar uma flexibilidade no absolutismo liberal clássico. No entanto, náo se olvida de que a propriedade continua sendo sinônimo de poder. Daí a sua ligação com o poder político. "Parece uma realidade que o poder econômico — seja representado pela detenção de propriedades imóveis, de bens de produção, de tecnologia ou valor mobiliário - constitui um dos pressupostos do poder político.” (TAVARES, 2003, p. 159).

Por isso, no presente ensaio, tem-se como foco a possibilidade da catividade marcaria ser um instrumento de responsabilização empresarial na sociedade de risco. Essa instrumentalidade da catividade marcária será construída em benefício de uma categoria específica de vulneráveis: os consumidores. Espera-se adiante justificar a possibilidade de adequação da catividade marcária aos fins propostos com base no ordenamento jurídico pátrio da responsabilidade civil.

5 REsp 586.316/MG, j. 17.04.2007, rel. Min. Herman Benjamim apud MARQUES; MIRAGEM, 2012, p. 184.

6 Cf. Artigo 5, incisos XXII e art. 170, II da Constituição Federal. No entanto, a função social é exigida também constitucionalmente como sombra de legitimação de sua titularidade (artigo 5º, inciso XXIII e artigo 170, incisos III da Constituição Federal.

7 Cf. Artigo 1228 do Código Civil Brasileiro. 


\section{Da Catividade Marcária}

O mercado de consumo se move iluminado por marcas nos painéis publicitários. $\mathrm{O}$ símbolo marcário, ou simplesmente a marca é qualquer signo distintivo que identifica a origem de produto ou serviço. Soares entende que:

[...] a marca é o sinal gráfico, figurativo ou de qualquer natureza, isolado ou combinado e que se destina à apresentaçáo do produto e/ou do serviço ao mercado. Por isso deve ser distintiva, especial e inconfundível. Consistindo a marca num sinal qualquer, e empregada essa palavra genericamente, subentende-se que marca é tudo, dispensando-se assim qualquer forma enumerativa, exemplificativa ou restritiva." (SOARES, 2000, p.16).

Portanto, tradicionalmente, a marca serve de referência para o consumo e influi diretamente nas escolhas de mercado. Portanto, "para as empresas as marcas representam uma propriedade legal incrivelmente valiosa que pode influenciar o comportamento do consumidor, ser comprada e vendida e, ainda, oferecer a segurança de receitas futuras e estáveis para seu proprietário". (KOTLER, 2006, p. 269). Assim, o produto ou serviço marcado, recorre a uma idéia pretérita de experiência positiva ou de renome num dado segmento de mercado, ou mesmo, em caso de marca nova, pretende marcar posição nesse sentido para que no futuro possa servir de referência.

A marca sempre foi vista como objeto do direito de propriedade. Nessa perspectiva o Direito sempre se ocupou de proteger a marca sob o prisma patrimonial, permitindo a sua exploração por aquele declarado seu titular. Internacionalmente, tem-se tanto a Convenção da União de Paris para a Proteção da Propriedade Industrial (CUP) ${ }^{8}$, como o Acordo sobre Aspectos dos Direitos de Propriedade Intelectual Relacionados ao Comércio 9 como principais instrumentos regulatórios da questão marcária. Constitucionalmente, sua proteção se encontra no art. 5\%, inc. XXIX, o que a coloca nos direitos fundamentais. Ademais, existe uma extensa regulação infraconstitucional, sendo disciplinada pela Lei no 9.279 de 1996, também denominada de Código da Propriedade Industrial, que dedica todo um título às marcas, e atribui competência ao INPI - Instituto Nacional de Propriedade Industrial ${ }^{10}$ para o registro dos símbolos como marca, segundo os critérios da novidade, veracidade, capacidade distintiva e da licitude. Assim, conforme alinhamento com

8 A CUP foi incorporada ao direito brasileiro pelo Decreto n. 75.572/1985.

9 Chamado de TRIPS, do inglês Agreement on Trade-Related Aspects of Intellectual Property Rights), integrante do conjunto de Acordos assinados em 1994, no encerramento da Rodada Uruguai do GATT (General Agreement on Tariffs and Trade), que criou a Organização Mundial do Coméricio (OMC), recepcionado no Brasil pelo Decreto n. 1.355, de 30 de dezembro de 1994.

10 O INPI foi criado pela Lei $N^{\circ} 5.648$, de 11 de dezembro de 1970. 
a regulação internacional a marca é passível de registro que atribui direito de exclusividade por um período de dez anos, que pode ser renovado por sucessivos e ilimitados decênios. ${ }^{11}$

Todo esse sistema está calcado na premissa da marca-propriedade. A marca como patrimônio do seu titular e, portanto, como bem objeto de uma propriedade absoluta e oponível aos terceiros, aos quais se impóe a obrigação negativa de não utilizar o signo protegido sem a necessária e prévia autorização. Assim, a marca é espécie de bem imaterial de natureza móvel. Para Negrão a marca é bem imaterial que:

\begin{abstract}
"Do ponto de vista do estabelecimento e identificando sua natureza jurídica, a marca pode ser conceituada como um direito de propriedade incorpóreo, integrante do estabelecimento, que tem como funçóes distinguir produtos e serviços e, em alguns casos, identificar sua origem e atestar o atendimento desses quanto a certas normas e especificaçóes técnicas." (NEGRÃO, 2010, p.167).
\end{abstract}

Sob a perspectiva informacional, as marcas são perfeitas à propagação pela sua apresentação imagética. A percepção humana, pelo sentido da visão, é um mecanismo natural de informação e configuração do espaço humano ou, ao menos, sua racionalização. A alfabetização marcária é prévia a alfabetização formal de uma língua. A razão é simples, nascemos conectados à rede informativa publicitária e, portanto, bombardeados pelas imagens das marcas.

Trata-se da idéia que as necessidades humanas como ilimitadas merece o amplo esforço atual para o seu atendimento. Justamente, aí, tem-se uma contínua criação e renovação de necessidades, num fenômeno sócio-econômico de inserção e pertencimento social, onde a publicidade é vital, pois atiça, consolida e constrói carências e desejos. Trata-se da função criativa ou persuasiva da publicidade.

"Há ainda uma função criativa na publicidade. Na verdade, a publicidade posta como elo entre os produtos, serviços, fornecedores, e os consumidores, acaba por criar conceitos, expectativas e necessidades. [...] Aqui a publicidade é verdadeira construtora de imagens (conceitos), e assim acaba provocando expectativas em seu destinatário, que não raras vezes apesar de não precisar do produto ofertado, acaba sentindo uma necessidade de adquiri-lo ou readquiri-lo." (CABRAL in PORTO, 2014, p. 84).

Nesse sentido, também expóe Dupas (2002, p. 51), a "comunicação e as mídias, os comunicadores e os publicitários, selecionam as imagens daquilo que querem que o mundo venha a ser, especialmente ornadas de artifícios sedutores e, por isso, mais vulneráveis.”

11 Lei no 9.279/96 (LPI) - Art. 133. O registro da marca vigorará pelo prazo de 10 (dez) anos, contados da data da concessão do registro, prorrogável por períodos iguais e sucessivos. 
Ademais, como aduz Nunes (2003, p. 58), a lógica da sociedade de consumo é no sentido de que "as necessidades são pretextos para vender aquilo que se produz. Assim, se não há necessidades, inventam-se e os desejos são produzidos juntamente com os bens."

$\mathrm{Na}$ divisão dos espaços representativos do trabalho e divertimento (playfulness) ${ }^{12}$, a publicidade não encontra limitação alguma. Tanto é possível sua inserção no trabalho quanto no divertimento. Assim, não há espaços sociais apublicitários ou não publicitários. Seja qual for o sítio, lá poderá está uma oportunidade de convite ao consumo.

Portanto, a marca é pensada como ativo de primeira ordem no mundo empresarial, pois constrói o feixe de valores (sofisticação, segurança, cuidado, etc.) que passam a se vincular à atividade exercida e, conseqüentemente, ao produto ou serviço que oferta. Nesse processo, os consumidores vão se identificando com esses valores, ou vão consolidando suas preferências com bases em experiências pretéritas positivas de consumo. Ao final, com o passar do tempo, a marca adquire renome e passa a ser o farol maior de referência na jornada de consumo. Batey ressalta o processo de marketing por trás de uma marca que aliado a experiência de consumo dos partícipes do mercado provocam o substrato do renome marcário.

\begin{abstract}
"Vale repetir que uma marca é criada não só como resultado das atividades de um marqueteiro (o estímulo, ou input), mas também - e isso é o principal - como resultado da leitura e da reação do consumidor a essas atividades (o que ele depreende da mensagem). Do ponto de vista do marqueteiro, a marca é uma promessa, um pacto. Da perspectiva do consumidor, é uma série de associaçôes, percepçôes e expectativas que existem em sua cabeça. \{...\} Com o tempo, experiências e encontros vão formando um conjunto de associaçóes, influenciado a percepção da marca e gerando a rede associativa, ou engrama da marca." (BATEY, 2010, p. 27 e 28)
\end{abstract}

A sociedade de consumo é resultado da sociedade de oferta, ou seja, o consumo se desenvolve a partir do incremento das atividades publicitárias. Justamente, nas publicidades ou propagandas em geral podemos entender que se encontra o habitat natural das marcas. Por isso, as marcas são, antes, projetos de captação da atenção dos consumidores, e se realizam no momento que essa percepção conquistada se transforma em opção de consumo. Eis a teia publicitária que aprisiona o consumidor, que inserido na sociedade de consumo, não está imune ao seu magnetismo imagético. A questão da cultura de oferta de que fala Bauman (2010, pp.33-34).

"A cultura de hoje é feita de ofertas, não de normas. Como observou Pierre Bourdieu, a cultura vive de sedução, não de regulamentação; de relaçóes

12 Utiliza-se aqui a proposta de classificação dos espaços sociais apresentada por HANNAH ARENDT (2010, pp.156-159). 
públicas, não de controle policial; da criação de novas necessidades/desejos/exigências, não de coerção. Esta nossa sociedade é uma sociedade de consumidores. E, como o resto do mundo visto e pelos consumidores, a cultura também se transforma num armazém de produtos destinados ao consumo, cada qual concorrendo com os outros para conquistar a atenção inconstante/errante dos potenciais consumidores."

Santos (2002, p.85) entende a globalização como um "[...] conjunto de relaçóes sociais que se traduzem na intensificação das interaçóes transancionais, sejam elas práticas interestatais, práticas capitalistas globais ou práticas sociais e culturais transnacionais”. $\mathrm{O}$ processo de globalização catapulta, via publicidade, as marcas a um patamar do consumismo global. Alie-se, nesse cenário, a transitoriedade das necessidades, representada, pela sua rápida renovação ou reincidência, o que faz com que os produtos e serviços, também, caracterizem-se pela pouca durabilidade, seja física ou funcional. "O consumismo de hoje não consiste em acumular objetos, mas em seu gozo descartável.” (BAUMAN, 2010, p. 42).

A força das marcas foi rapidamente compreendida pelo direito que tratou de protegê-la. É o triunfo da marca-propriedade. A exaltação da marca é produto de estratégias e diretrizes econômicas de dominação de mercados resultantes da sua essencialidade ao sistema capitalista ${ }^{13}$. Por isso, em termos econômicos, passou-se a explorar uma marca de formas múltiplas, principalmente, por compartilhamento marcário. São diversos os contratos que passaram a tratar de compartilhamento de marcas. Franquia, concessão, representação, licença e co-branding são alguns exemplos de compartilhamento. A idéia de exercício de uma composse marcária promove, ao final,o crescimento do renome da marca, seja pela consolidação em seu mercado, seja pelas conquistas de novos espaços pelos compossuidores.

O problema é que, consciente de uma sociedade de risco, é possível se superar a exclusividade do aspecto marca-propriedade. Afinal, no fenômeno global, há riscos próprios do universo econômico empresarial. Não se pode perder de vista o mandamento constitucional, no art. $3^{\circ}$, I, onde o desenvolvimento deve levara uma sociedade livre, justa e solidária. Assim, a marca-propriedade deve ter uma efetiva função social da propriedade. Afinal, existe uma marca-risco. As marcas atraem os consumidores e os expóe aos perigos do consumo, aos seus acidentes que passam desde aos danos materiais, mas que colocam em xeque à própria saúde e segurança dos usuários.

13 Observe-se que o sistema internacional da propriedade industrial é criado, ainda, no fim do século XIX com a Convenção da União de Paris - CUP (1883). O Brasil foi um dos 14 (catorze) países signatários. No entanto, a consolidação do sistema internacional da propriedade industrial ocorreu, durante o século XX, nas revisóes da CUP, desde Bruxelas (1900), passando por Washington (1911), Haia(1925), Londres (1934), Lisboa (1958) e Estocolmo (1967). Atualmente, tem-se a impressionante adesão de 176 signatários <http://www.wipo.int/treaties/en/ShowResults.jsp?lang=en\&treaty_id=2> Acesso em 02 de junho de 2015. 
A vulnerabilidade dos consumidores dependentes dos produtos e serviços para satisfação de suas necessidades vai desde a impotência em relação ao que lhe é ofertado, passando pela assimetria de informaçôes em relação ao fornecedor e vai até mesmo a extrema dificuldade de identificar, para além da marca, quem é o real responsável pelo produto ou serviço adquirido.

"No mundo atual, o déficit informacional dos consumidores é cada vez mais profundo. A jurisprudência, porém, está demonstrando uma tendência de valorizar as informaçóes prestadas, mesmo que através da marca ou aparência, e daí tirando instrumentos de compensação desta vulnerabilidade intrínseca do papel de consumidor." (MARQUES; MIRAGEM, 2012, p. 15).

De fato, o único ponto facilmente perceptível no mercado de consumo são as marcas. Essa vulnerabilidade, ou seu reconhecimento, é relevante valor social na condução econômica, o que reflete ainda na principiologia da ordem econômica de proteção geral aos consumidores.

O mercado deve ter um espírito igualitário de regras comuns, para que se possa desenvolver um jogo justo, uma disputa igualitária. Contudo, a concorrência obriga aos empresários a desenvolver uma diferenciação dos demais concorrentes para que possam ser notados em um mercado, cada vez mais, global. Ou seja, a igualdade cede à desigualdade, para que o agente de mercado possa se diferenciar. A marca como elemento distintivo serve à desigualdade.

$\mathrm{Na}$ idéia de que "existir não é somente ser diferente, mas também ser reconhecido legitimamente diferente e em que, por outras palavras, a existência real da identidade supóe a possibilidade real, juridicamente e politicamente garantida, de afirmar oficialmente a diferença - qualquer unificação, que assimile aquilo que é diferente, encerra o princípio da dominação de uma identidade sobre a outra, de negação de uma identidade por outra." (BOURDIEU, 2010, p. 129)

Em qualquer disputa, cada concorrente busca o melhor para si. O sistema econômico mundial é por essência conflituoso. Wallerstein (1976, p. 229-233) demonstra que:

"Um sistema-mundo é um sistema social, que tem limites, estruturas, grupos de membros, regras de legitimação e coerência. A sua vida é formada por forças em conflito que o mantém unido pela tensão e o separa na forma como cada grupo procura, eternamente, para remodelá-lo a seu favor."

O elemento identificador da marca serve, não só aos consumidores que passam a ter uma referência de origem, mas também aos concorrentes do fornecedor marcado, que 
identificam os seus aliados ou rivais. Os agentes econômicos jogam uniformizados pelas marcas.

\begin{abstract}
"a marca serve como uma espécie de uniforme identificador das equipes partícipes do jogo concorrencial. Entretanto, há nítida dificuldade de se identificar os contornos dessas relaçóes e suas consequências no direito econômico e do desenvolvimento." (VASCONCELOS; CABRAL, 2014).
\end{abstract}

A marca indica a origem da oferta, quem é o proponente do consumo. No reconhecimento de Kotler (2006, p. 22) a "[...] marca é uma oferta de uma fonte conhecida." Contudo, é a diferenciação é que atrai o consumidor, conquistando sua opçáo por uma primeira experiência de consumo (captação inaugural) ou, o mais cobiçado pelos fornecedores, manter-se como opção permanente de consumo (fidelidade). Essa vis attractiva marcária não pode ser compreendida como um fenômeno estritamente econômico, mas deve ser reconhecida como importante aspecto cultural e social da pós-modernidade. Portanto, a marca faz bem mais que apontar origem do produto, ela materializa uma ideia, um conceito, um comportamento, uma expectativa iminente de satisfaçáo de desejos.

Quessada (2003, p. 12) exprime o seguinte pensamento: "Por seu trabalho de imposição de ordens e de vetorização da ordem (de organização da ordem), a publicidade consiste fundamentalmente na criação e na definição de territórios (os territórios das marcas) aos quais aderem pessoas." Não à toa a marca se tornou ativo de primeira ordem no patrimônio empresarial.

Fortunas são dispensadas na construção das marcas, por meio de campanhas publicitários e profissionais cada vez mais especializados na construção de marcas respeitadas. "Cria-se um sistema de retroalimentação em que a publicidade, como espécie de comunicação social de massa, fortalece a marca que ostenta e, por outro lado, a marca fortalece a própria publicidade que a propaga." (VASCONCELOS; CABRAL, 2014).

A força desse processo é tanta que temos denominado o momento em que vivemos de a era Times Square, em referência a um dos pontos turísticos mais visitados no mundo. ${ }^{14}$

$\mathrm{Na}$ famosa praça nova-iorquina, os olhos de todos estão nas marcas propagadas em grandes telóes publicitários que convidam ao consumo de forma ininterrupta,

Na era Times Square, todo lugar é mercado, o discurso é publicitário, o patrimônio mais valioso é intangível ${ }^{15}$, todos são consumidores, e o fim

14 Estima-se que cerca de50 milhões de turistas estiveram na Times Square em 2013. CF. <http://veja.abril. com.br/noticia/mundo/lista-os-dez-pontos-turisticos-mais-visitados-no-mundo/>>. Acesso: 05 de Maio 2015.

15 A própria marca é contabilmente um ativo intangível. 
é o poder econômico. Só se tem significado o que se associa a um valor consumível, as pessoas pertencem às tribos sociais que ostentam seus totens (suas marcas) como senhas essenciais de inserção e permanência em seu seio coletivo. O indivíduo é o que consome, seja vestindo, bebendo, viajando etc. (VASCONCELOS; CABRAL, 2014).

O idioma de mercado precisa ser eficiente aos seus fins e apto a se comunicar com dinamismo. Nesse contexto, a marca instrumentaliza uma comunicação célere e eficiente com os consumidores. Mais que a origem do produto e suas especificaçóes, a marca tenta passar um grupo axiológico atraente aos consumidores. Inclusive, com o passar do tempo, as experiências de consumo do próprio indivíduo interfere nessa relaçáo informacional e adere ao substrato de valores da marca. Assim, há uma interaçáo de elementos objetivos (discurso, imagens, publicidades) e subjetivos (experiências de consumo individuais) na construção do ideário marcário. Solomon (2011, p. 32) destaca que as "pessoas quase sempre escolhem um produto porque gostam de sua imagem ou porque acreditam que sua 'personalidade', de alguma maneira, corresponde à delas".

Fortalecida a marca, ela passa a ter ainda mais potencial de assumir a posição de objeto próprio das relaçóes negociais no mundo empresarial. Uma grande marca faz com que ela seja melhor negócio que o produto que antes ela identificava. Por isso, com a evolução das estratégias de ocupação de mercado, foram sendo criadas, cada vez mais, novas formas de contratos que atraiam a marca para seu contexto.

Logo, surgem contratos múltiplos, conexos, cativos, entre outros numa denúncia da proliferaçáo de novas formas de se relacionar no mercado da pós-modernidade. Os contratos cativos consistem numa série de contratos ou relaçôes contratuais que criam relaçōes jurídicas complexas de longa duração envolvendo agentes econômicos de uma cadeia de fornecimento e impondo uma posição de dependência ou catividade dos consumidores. Isso se coaduna com o perfil atual de indução ao consumo de bens materiais ou não através de exposição à publicidade agressiva, além de outras estratégias de marketing, que expóem os consumidores a graves riscos na vida em sociedade e produzem grande insegurança quanto ao futuro, portanto são exemplos desses contratos cativos os bancários, fornecimento de água, luz e telefone, entre outros. (VASCONCELOS; CABRAL, 2014).

Marques (2006, pp. 91-92) explicita a noção dos contratos que denomina de "cativos":

Trata-se de uma série de novos contratos ou relaçóes contratuais que utilizam os métodos de contratação de massa (através de contratos de adesão ou de condiçóes gerais dos contratos) para fornecer serviços especiais no mercado, criando relaçôes jurídicas de longa duração, envolvendo uma 
cadeia de fornecedores organizados entre si e com uma característica determinante: a posição de 'catividade' ou 'dependência' dos clientes, consumidores.

Quando o titular de uma marca resolve compartilhar sua marca com outro fornecedor, ele irá configurar um contrato que permita esta operação, e, obviamente, permita trazer as vantagens que legitimamente espera, bem como o proteja como titular da marca. Contudo, as formas idealizadas de compartilhamento marcário, seja licença, franquia, concessão, co-branding, ou outra que inclua a composse marcária, acabam por afetar interesses de terceiros, pois, ao final, o mercado consumidor náo é informado das exatas definiçôes de limites do uso do símbolo entre os contratantes. Ou seja, para o consumidor, muita vezes, sequer se percebe que uma dada marca está sendo ofertada por outro fornecedor com a devida permissão do titular marcário. Interessante a proposta de Konder (2006, p. 189) para a caracterização do fenômeno da conexidade contratual.

São conexos os contratos que, para além de sua função individual específica, apresentam juntos uma função ulterior. Em virtude de sua ligação, aqueles negócios estruturalmente independentes perseguem uma finalidade que ultrapassa a mera soma das suas próprias finalidades individuais.

Assim, o titular de uma marca quando a explora por meio de sucessivos contratos de licença com partes contratantes, ainda que distintas, por mais que sejam negociaçóes independentes, mais do que o negócio de cada um, a rede de compartilhamento marcário formada, interessa a todos, pois o uso reforçado da marca pelo grupo, fortalece seu conceito perante o mercado como um símbolo de força.

Finalmente, a realidade de compartilhamento marcário por sua força atrativa alinhase ao pensamento exposto acerca dos contratos cativos, pois as marcas se fortalecem por meio de método de massificação publicitária, aprisionando os consumidores pela apreensão de seus desejos e necessidades numa cadeia de fornecedores.

A catividade marcária é fundamentada no fato de que as escolhas e preferências dos consumidores se pautam na marca, pois nela se deposita o conceito ou renome como variante de decisão de aquisição. Variante qualitativa seja pelo atributo de procedência, de antiguidade no mercado, ou mesmo, associativa, que remete às experiências pretéritas de consumo e de satisfação de necessidades similares anteriormente manifestadas. (VASCONCELOS; CABRAL, 2014).

Pelo exposto, se coloca a ideia da catividade marcária como um fenômeno socioeconômico que representa a vis attractiva das marcas que apreende os desejos dos consumidores e adquirentes em geral, seja sedução do discurso publicitário criador de valores e necessidades. A catividade marcária representa um processo de dominação de espaços 
por construção de uma afinidade calculada entre consumidores e marcas, que se relacionam na aprisionadora rede de ofertas inexoravelmente nos espaços públicos e privados de convívio social na era pós-moderna.

\section{Catividade Marcária como Fundamento da Responsabilidade Civil Empre- sarial por Risco em Prol dos Consumidores}

A responsabilidade é um atributo reativo do Estado para ação do sujeito de direito que é indesejada a luz do sistema jurídico. Sob a perspectiva civil, a conduta provocadora de um decréscimo patrimonial ou causadora da perda de um provável e legítimo acréscimo no patrimônio alheio pode ensejar o dever de recomposição ou indenização dessas situações tidas por danosas.

Entre tantas teorias que fundamentam o abraço da responsabilização civil, destacase, para fins do presente estudo, a teoria do risco. A escolha dessa teoria, embora fundamentada em risco com carga semântica distinta daquela trazida por Beck, justifica-se pela preocupação compartilhada da idéia de que os perigos criados por açóes de uns podem atingir outros, que são sujeitos totalmente alheios a causa do dano. Ou seja, existem agentes cujas condutas provocam riscos que, se causarem danos, devem ser de responsabilidade de seus patrocinadores.

A seara da responsabilidade civil está sempre permeada pela noção de equidade. A justa recomposição ao lesado sofredor do dano pelo agente que o provocou. Ademais, a contrapartida entre ação e reação, a simetria entre ônus e bônus estão sempre a inspirar o fenômeno da responsabilização.

A responsabilidade objetiva funda-se num princípio de equidade, existente desde o direito romano: aquele que lucra com uma situaçáo deve responder pelo risco ou pelas desvantagens dela resultantes (ubi emolumentum, ibi onus; ubi commoda, ibi incommoda). Quem aufere os cômodos (ou lucros), deve suportar os incômodos (ou riscos). (GONÇALVES, 2012, p. 29)

No Código Civil brasileiro o disciplinamento da responsabilidade civil está previsto no art. 927, associado ao arts. 186 e 187 como regra inicial. Desses dispositivos, concluise que a responsabilidade civil (art. 927) seria subjetiva, portanto, atrelada a idéia de culpa por negligência ou imprudência (art. 186), ou pelo abuso de direito (art. 187). Contudo, o ordenamento jurídico brasileiro traz a regra da responsabilidade objetiva quando se fala em dano causado por atividade de risco, nos exatos termos do art. 927, parágrafo único, "Haverá obrigação de reparar o dano, independentemente de culpa, nos casos especificados em lei, ou quando a atividade normalmente desenvolvida pelo autor do dano implicar, por sua natureza, risco para os direitos de outrem.” (BRASIL, 2015). 
Portanto, não há dúvidas quanto à aplicabilidade da teoria do risco para fins de reparação dos danos causados por atividades empresariais, pois está abrangida pela idéia legal de "atividade". A atividade empresarial é espécie do gênero "atividade" econômica. Esse dispositivo, não muito estudado abre um grande espaço de aplicação, pois amplia as possibilidades de adoção da teoria do risco no fenômeno da responsabilização, pois além dos óbvios casos em que a lei especificar o dever de indenizar pelo risco, permite a regra em comento o reconhecimento judicial de um conceito aberto de "atividade que implica, por sua natureza, risco para os direitos de outrem". É o que se infere do dispositivo de forma cristalina.Segundo Vasconcelos (2003, p. 162) "quando a atividade normalmente desenvolvida pelo autor do dano implicar, por sua natureza, risco para os direitos de outrem" uma nova responsabilidade é possível em decorrência da inovação que trouxe o art. 927 do Código Civil de 2002 que elege aplicar a responsabilidade objetiva.

No regime anterior, as atividades perigosas eram somente aquelas assim definidas em lei especial. As que não o fossem enquadravam-se na norma geral do Código Civil, que consagrava a responsabilidade subjetiva. $\mathrm{O}$ referido parágrafo único do art. 927 do novo diploma, além de não revogar as leis especiais existentes, e de ressalvar as que vierem a ser promulgadas, permite que a jurisprudência considere determinadas atividades já existentes, ou que vierem a existir, como perigosas ou de risco. Essa é, sem dúvida, a principal inovação do Código Civil de 2002, no campo da responsabilidade civil. (GONÇALVES, 2012, p. 30)

O conceito de risco, portanto, passa a ser entendido como a exposição de perigos que devem ser combatidos pelo exercente da atividade. Na hipótese, de tais riscos, resultarem em danos efetivos a terceiro, não haveria solução mais natural que o dever de recomposição ou compensação por seu causador. Desse modo, a jurisprudência vem reconhecendo situaçóes em que pessoas sujeitos lesados por exposição aos riscos merecem indenização pelo patrocinador da atividade. É o caso dos danos sofridos em acidentes aéreos $^{16}$, atropelamentos ${ }^{17}$, e acidentes de trabalho ${ }^{18}$, por exemplo.

A determinação do parágrafo único do art. 927 do Código Civil, como dispositivo aberto, deve ser interpretada a luz da realidade contemporânea. Náo raras vezes, a atividade econômica exercida por certo agente causa danos, mas a identificação real desse agente é dificuldade por meio de estratégias organizacionais societárias. Na prática, em

16 Cf. TJ-SC - AC: 50920 SC 1999.005092-0, Relator: Dionizio Jenczak, Data de Julgamento: 13/06/2003, Terceira Câmara de Direito Civil, Data de Publicação: Apelação cível n. 1999.005092-0, de Itajaí.

17 Cf. STJ - REsp: 185659 SP 1998/0060138-4, Relator: Ministro CARLOS ALBERTO MENEZES DIREITO, Data de Julgamento: 26/06/2000, T3 - TERCEIRA TURMA, Data de Publicaçáo: DJ 18.09.2000 p. 126 RSTJ vol. 150 p. 26.

18 Cf. TST - RR: 2408220125150112, Relator: Maria de Assis Calsing, Data de Julgamento: 25/03/2015, 4a Turma, Data de Publicação: DEJT 31/03/2015. 
sua atuação de mercado os grupos ou blocos empresariais só são identificados pelas marcas que compartilham. Surge, daí, gama diversificada de tipos contratuais, que, no entanto, querem apenas co-usufruindo benefícios do renome marcário, mas pretendem autonomia em termos de responsabilização, com o fim de isentar das consequências do seu mau uso, ou riscos, alguns contratantes formadores das cadeias de fornecimento.

Marques (2006, p. 92) trata a catividade como o fenômeno de indução ao consumo de bens, da publicidade massiva e métodos de marketing agressivos, tudo isso, gerando "graves e renovados riscos na vida em sociedade e de grande insegurança quanto ao futuro."

O estudo da responsabilização civil no fenômeno marcário como instrumento regulatório empresarial avulta de importância nas relaçóes massificadas em que a vulnerabilidade do consumidor é acentuada, especialmente face à intensa atração exercida pelas marcas. A leitura parte, agora, da idéia de proteçáo e valorização da dignidade humana. A defesa de Barroso (2010), onde o direito não mais se encerra na visão patrimonialista, pois a dignidade da pessoa humana como espectro axiológico do sistema e base central da ordem jurídica internacional tem como corolário o princípio da solidariedade social, extraído do art. $3^{\circ}$, I da CF. Danos não podem ser suportados pelos mais vulneráveis. Enquanto que, em outro norte, os fornecedores que compartilham marcas se abastecem das vantagens de suas alianças, devem também cooperar nos riscos criados. Caberia, cada vez mais, ao Direito promover a cooperação entre os indivíduos na realização dos fins da sociedade contemporânea. (HIRONAKA, 2002).

Ademais, deve-se valorizar a função social dos pactos, para isso a observação dos interesses sociais, principalmente dos não contratantes, em jogo. "Um dos principais efeitos da função social dos contratos é a consideração de interesses não contratantes em sua tutela, de maneira a perceber o contrato inserido em seu contexto social." (KONDER, 2006, p. 274). Quando fornecedores resolvem pactuar o uso comum de marcas, eles passam a mensagem de atuação coordenada e devem por isso compartilhar a assunção dos riscos. Os consumidores, ao observarem o mesmo símbolo nas atividades, interpretam e esperam uma cooperação entre aqueles que ostentam marcas iguais.

O compartilhamento marcário permite que os fornecedores da cadeia contratual obtenham vantagens, logo há a necessidade de ponderaçóes de ordem econômica e empresariais para distribuição de riscos. Em prol do desenvolvimento, conforme leciona Calixto Filho (2002, p. 39), "muito mais do que instrumento para o desenvolvimento a idéia de redistribuição integra o próprio conceito de desenvolvimento". Essa divisão é proposta como derivação da exploração conjunta de determinada marca, porque permite essa redistribuição e o verdadeiro desenvolvimento o que pode ser visto como processo de expansão da segurança contra os riscos criados. Na visão de Sen (2000, p. 52), desenvolvimento é “[...] um processo de expansão das liberdades reais que as pessoas desfrutam." 
O referido dispositivo do parágrafo único do art. 927 do Código Civil permite ao intérprete a construção de hipóteses, para além de leis especiais, de responsabilidade por risco. E, aqui, o que se pretende é demonstrar a viabilidade de adequação da catividade marcária como fundamento para o abraço deste tipo de responsabilidade em prol de uma categoria reconhecidamente vulnerável que é a dos consumidores. Como afirma Bittar (2002, p. 117).

Com a complexidade inerente às relações econômicas também é sentida na impossibilidade de ter-se uma legislação cuja amplitude semântica seja capaz de abarcar todos os comportamentos econômicos possíveis, mormente em tempos de globalização e de atipicidade das diversas formas de estabelecimento de relaçóes contratuais.

E, sendo a responsabilidade civil um sistema de preservação patrimonial, a questão que surge é "Qual a propriedade deve ser privilegiada, a do consumidor mais vulnerável, ou a do fornecedor que se beneficia das marcas que compartilha?". Obviamente, discute-se, aqui, poder. A responsabilidade civil pode ser instrumento de justiça social e do reequilíbrio da relação consumerista, com base na catividade marcária, reconhecendo-se um novo poder em auxílio ao consumidor lesado.

Sob a perspectiva do risco, suponha-se o problema da contratação de um plano de saúde nacional, que denominaremos, hipoteticamente, de "MED-UNION" que promete cobertura nacional aos seus usuários, que se denomina fazer parte de uma rede que ostenta a mesma logomarca. Ora, o consumidor passa identificar que todo estabelecimento de saúde, hospital, clínicas, consultórios em geral, onde há a aposição do símbolo marcário "MED-UNION", são integrantes da mesma rede de fornecimento. Contudo, em viagem em outra localidade diferente de seu domicílio, o usuário procura um atendimento médico em entidade que ostenta a mesma marca "MED-UNION", mas tem sua pretensão negada, por ser outra pessoa jurídica "MED-UNION São Paulo" e não conveniada à pessoa jurídica contratada pelo paciente "MED-UNION Rio", por exemplo.

O mesmo ocorre com a aquisição de um produto de uma marca no exterior, em que, já no Brasil, o consumidor observa um defeito no produto. A escolha do produto se deu com base na marca, porém, no Brasil, a pessoa jurídica responsável pelo produto com a mesma marca alega não ter responsabilidade, inclusive, comumente se alega a existência de quadro societário diverso.

Dentro de uma rede de contratos conexos, as hipóteses são plurais, pode-se ter desde uma relação societária, até um mero contrato de licenciamento marcário. E, dentro dos padróes ordinários de interpretaçáo do fenômeno da responsabilidade civil, a busca pela individualidade da culpa ou do agente, pode-se ter respostas bem distintas quanto ao dever ou não de indenizar. $\mathrm{O}$ que se defende é que, a marca foi elemento atrativo essencial, sendo decisiva manifestação volitiva do consumidor. 
O famoso caso da filmadora "PANASONIC", onde o STJ decidiu pela responsabilidade de uma pessoa jurídica brasileira quanto ao produto fabricado no exterior com a menção expressa à "respeitabilidade da marca" e a busca de equilíbrio entre o ônus das "deficiências dos produtos" e o bônus da fruição "de marcas mundialmente conhecidas"19. Da mesma forma, a primeira turma recursal cível do TJRS reconheceu o vínculo por meio da marca entre fabricante estrangeira e importadora nacional ${ }^{20}$.

Os precedentes citados demonstram que a marca pode ser o vetor de responsabilização, o que se precisa é o encontro de um espaço próprio, no ordenamento jurídico posto, para a fundamentação das decisóes. Assim, nessa linha de raciocínio, a catividade marcária aliada à construção da idéia de risco é capaz de permitir a efetiva proteção do consumidor, com a conquista de sólido território de fundamentação via o próprio parágrafo único do art. 927 do Código Civil. Ademais, não se pode olvidar que, na economia global, as trocas de bens são impulsionadas sem publicidades com marcas globais, assim o campo de atuação das marcas não tem fronteiras, repercutindo em relaçôes jurídicas para além de qualquer limitação dos territórios nacionais.

Importante, no entanto, deixar evidenciado que a catividade marcária não se limita ao cenário global de grandes empresas e marcas. Trata-se de fenômeno modular de aprisionamento das preferências dos consumidores, reproduz-se, também em espaços mais restritos, seja nacionalmente e, até, regionalmente. Dessa forma, a internacionalidade, embora fortaleça a teoria da catividade marcária, não consiste em elemento sine qua non para o seu reconhecimento.

Na pavimentação de uma maior proteção aos consumidores, uma abrangência semântica quanto ao risco é necessária. As teorias de Beck e Giddens, embora dedicadas com maior ênfase à preocupação de grandes riscos ou riscos civilizatórios como forma de responder as necessidades de uma nova realidade mais complexa, não deixam de reconhecer a existência de outros riscos menores. Esse parece ser o campo em que a idéia de catividade marcária pode contribuir, entre os riscos de consumo individuais. A catividade marcária está apta a fundamentar a responsabilidade civil empresarial por risco em prol dos consumidores.

\section{Conclusões}

A premissa de nosso estudo é a catividade marcária, assim, reconhece-se no símbolo marcário a capacidade de influência comportamental dos consumidores. Sáo os signos

19 Cf. REsp 63.981/SP, Rel. Ministro ALDIR PASSARINHO JUNIOR, Rel. p/ Acórdāo Ministro SÁLVIO DE FIGUEIREDO TEIXEIRA, QUARTA TURMA, julgado em 11/04/2000, DJ 20/11/2000, p. 296.

20 BRASIL. Tribunal de Justiça do Rio Grande do Sul. Recurso Cível no 71001234657 da $1^{\text {a }}$ Turma Recursal Cível. Relator: Ricardo Torres Hermann. Porto Alegre, 24 maio 2007. 
marcários os sinalizadores de consumo. Nessa vertente, na tentativa de superação da consolidada vertente liberal, da marca-propriedade, tem-se que pensar na marca-risco. Nessa última perspectiva, a marca deve ser redefinida por uma construção de sua função social. Função social, portanto, repaginada à luz da sociedade atual, a sociedade de risco.

A responsabilização civil dos empresários com fundamento na catividade marcária outorga novo e importante aspecto à função social das marcas. Explorar o mercado, seduzi-lo e conquistá-lo por meio de marcas construtoras de necessidades, desejos e conceitos, implica em assumir riscos empresariais, inclusive nas diversificadas hipóteses de compartilhamento de marcas. Como visto, a respaldo legal que dê suporte ao uso da catividade marcária na hipótese de responsabilização por riscos com fulcro no parágrafo único do art. 927 do Código Civil.

Assim, mais uma vez, a teoria da catividade marcária serve de fundamento para a responsabilizaçáo empresarial nas relaçóes de consumo, e de outros vulneráveis, tais como trabalhadores, idosos, até as futuras geraçóes. A responsabilidade civil precisa rever seus conceitos tradicionais para buscar responder os desafios da sociedade pós-moderna, com suas cadeias de fornecimento em feixe e de difícil individualização de condutas.

O hegemônico sistema econômico capitalista resulta inexoravelmente nas multiplicaçóes dos riscos. Eis a sociedade do risco de que fala Beck. Os riscos são incontroláveis e causadores de danos, desde os altos perigos criados que póe em risco a civilização, até os menores, que, embora individuais, replicam-se exponencialmente, principalmente, em grupos mais frágeis. Esses grupos possuem maior predisposição ao dano, e, pior, sua situação os coloca em desvantagem mais acentuada, ainda, quanto à capacidade de absorção do evento danoso.

Assim, no mercado, as atividades geradoras de riscos e danos, ocorrem em prol da negociação de produtos e serviços que são gravados por símbolos promotores apostos em suas embalagens, publicidades e açóes em geral: as marcas. As divisóes de tarefas na cadeia de desenvolvimento não são publicizadas com clareza, por isso as complexas redes de contratos instrumentalizam interesses comuns ocultos, mas que podem ser identificados pelas marcas. Por isso, aos consumidores é dificultada a compreensão da estrutura organizacional dos grupos econômicos formais e informais. Assim, a marca serve de pedra de toque para identificação dos grupos econômicos de fato, por meio do seu compartilhamento.

A catividade marcária adéqua-se como fundamentação jurídica para promover o desenvolvimento socioeconômico do mercado consumerista ao redistribuir os riscos empresariais. Ao desempenhar este papel, a teoria em questão socializa as conseqüências danosas entre os membros da cadeia de fornecimento e permite a efetividade da tutela reparatória diante da vulnerabilidade dos consumidores. A ideia esposada milita em favor de uma regulação econômica desenvolvimentista, na sociedade de risco, de forma a evitar que 
estes, embora sejam sociais, recaiam, insistentemente, com maior incidência em grupos vulneráveis. Ademais, na ordem atual, proteção efetiva não pode se render as limitações geográficas, afinal, as marcas são globais.

A tentativa, aqui esboçada, é de fortalecer a fundamentação da catividade marcária para seu papel de vetor de responsabilização empresarial. Da mesma forma, insiste-se na busca de uma sociedade mais justa e solidária, por meio da efetividade de uma função social marcária, cujo escopo último continua sendo o aperfeiçoamento do sistema econômico e concorrencial quanto à tutela dos grupos vulneráveis.

\section{Referências}

ALEXANDRE, Agripa Faria. A dinâmica da sociedade de risco segundo Antony Giddens e Ulrich Beck. Geosul, Florianópolis, v. 15, n. 30, p. 150-167, jan. 2000. ISSN 2177-5230. Disponívelem: <https://periodicos.ufsc.br/index.php/geosul/ article/view/14312>. Acesso em: 09 Jun. 2015. ARENDT, Hannah. A condiçáo humana. Tradução Roberto Raposo. 11 ed.Rio de Janeiro: Forense Universitária, 2010.

BARROSO, Luís Roberto. Curso de Direito Constitucional Contemporâneo. São Paulo: Saraiva, 2010.

BATEY, Mark. $\mathrm{O}$ significado da marca: como as marcas ganham vida na mente dos consumidores. Rio de Janeiro: Best Business, 2010.

BAUMAN, Zigmunt. Capitalismo parasitário. Trad. Eliana Aguiar. Rio de Janeiro: Jorge Zahar Editor, 2010.

BECK, Ulrich. Sociedade de risco: rumo a uma outra modernidade. São Paulo: Editora 34, 2013.

BITTAR, Carlos Alberto. Tutela dos direitos da personalidade e dos direitos autorais nas atividades empresariais. São Paulo: Revista dos Tribunais, 2002.

BOURDIEU, Pierre. O poder simbólico. Rio de janeiro: Bertrand Brasil, 2010.

BRASIL, Código Civil. Disponível em: <planalto.gov.br>. Acesso em: 05 junho 2015.

CABRAL, André Luiz Cavalcanti. O fenômeno Publicitário: um estudo conceitual e funcional. In: PORTO, Elisabete Araújo (Org.). Contribuiçóes para a ciência jurídica à luz dos direitos sociais. Rio de Janeiro: Publit, 2014. Cap. III, p. 70 - 95.

CAMARGO, Ricardo Antônio Lucas. Direito Econômico: aplicaçáo e eficácia. Porto Alegre:Sérgio Antonio Fabris Editor, 2001.

DUPAS, Gilberto. Ética e Poder na Sociedade da Informação. 2 ed. São Paulo: Editora UNESP, 2001. 
GONÇALVES, Carlos Roberto. Direito Civil Brasileiro. São Paulo: Saraiva, 2012.

HIRONAKA, Giselda Maria Fernandes Novaes. Responsabilidade pressuposta. São Paulo: USP, 2002.

KONDER, Carlos Nelson. Contratos Conexos. Grupos de contratos, redes contratuais e contratos coligados. Rio de Janeiro: Renovar, 2006.

KOTLER, Philip. Administraçáo de marketing. Trad. Mônica Rosenberg, Brasil Ramos Fernandes, Cláudia Freire. 12 ed. São Paulo: Pearson Prentice Hall, 2006.

LISBOA, Senise. Responsabilidade Civil nas Relaçóes de Consumo, RT, 2001.

MARQUES, Cláudia Lima. Contratos no Código de Defesa do Consumidor. 5 ed. rev. atual. ampl. São Paulo: Rt, 2006.

MARQUES, Cláudia Lima; MIRAGEM, Bruno. O novo direito privado e a proteçáo dos vulneráveis. São Paulo: Revista dos Tribunais, 2012.

NEGRÃO, Ricardo. Manual de direito comercial e de empresa: teoria geral da empresa e direito societário. v. 1. $7^{\mathrm{a}}$ ed. São Paulo: Saraiva, 2010.

NUNES, António José Avelãs. Neoliberalismo e Direitos Humanos. Rio de Janeiro: Renovar, 2003.

QUESSADA, Dominique. O poder da publicidade na sociedade consumida pelas marcas: como a globalizaçáo impóe produtos, sonhos e ilusóes. Tradução de Joana A. D. Melo. São Paulo: Futura, 2003.

SALOMÃO FILHO, Calixto. (coord) Regulação e Desenvolvimento. São Paulo: Malheiros, 2002.

SANTOS, Boa ventura de Souza. (org). A Globalização e as Ciências Sociais. 2 ed. São Paulo: Cortez, 2002.

SEN, Amartya. Desenvolvimento como Liberdade. São Paulo: Companhia das Letras, 2000.

SOARES, José Tinoco. Marca vs nome comercial: conflitos. São Paulo: Jurídica Brasileira, 2000.

SOLOMON, Michael R. O comportamento do consumidor: comprando, possuindo e sendo. Trad. Luiz Carlos de Queiroz Faria. 9 ed. Porto Alegre: Bookman, 2011.

TAVARES, André Ramos. Direito constitucional econômico. São Paulo: Método, 2003.

VASCONCELOS, Fernando A. Internet: responsabilidade do provedor pelos danos praticados. Curitiba, Editora Juruá, 2003. 
VASCONCELOS, Fernando Antonio; CABRAL, André Luiz Cavalcanti. Catividade marcária como fundamento da responsabilidade civil do fornecedor por fato do serviço. In: I ENCONTRO DE INTERNACIONALIZAÇÃO DO CONPEDI, Barcelona, 2014. Anais. Barcelona: Conselho Nacional de pesquisa e pós-graduação em Direito, 2014. 